\title{
POTENSI REMPAH-REMPAH TRADISIONAL SEBAGAI SUMBER ANTIOKSIDAN ALAMI UNTUK BAHAN BAKU PANGAN FUNGSIONAL)
}

\section{(The Potential of Traditional Spices as a Source of Natural Antioxidants for Functional Food Raw Materials)}

\author{
Andi Widya Helmalia ${ }^{1)}$, Putrid ${ }^{1)}$, dan Andi Dirpan ${ }^{1 *}$ \\ ${ }^{1}$ Program Studi Ilmu dan Teknologi Pangan, Universitas Hasanuddin, Makassar, Indonesia \\ *) email Penulis Korespondensi: dirpan@unhas@ac.id
}

\begin{abstract}
ABSTRAK
Seiring dengan perkembangan zaman yang semakin maju, masyarakat semakin sering mengkonsumsi makanan cepat saji atau junk food. Hal inilah yang menyebabkan munculnya penyakit degeneratif berdasarkan pola hidup. Sehingga muncullah konspe pangan fungsional. Pangan fungsional adalah makanan atau minuman yang memiliki fungsi fisiologis terhadap tubuh. Misalnya mengkonsumsi antioksidan untuk dapat menangkal radikal bebas yang terjadi pada tubuh. Sumber antioksidan alami ini dapat berasal dari berbagai jenis tumbuhan seperti buah-buahan, sayur-sayuran, rempah-rempah, teh, ataupun enzim dan protein Seperti yang telah kita ketahui, Indonesia merupakan negara yang kaya akan rempah-rempah. Rempah-rempah ini dapat digunakan sebagai sumber antioksidan alami yang memiliki banyak manfaat bagi tubuh. Jenis-jenis rempah yang ada di Indonesia yaitu jahe, kunyit, kayu manis, secang, dan andaliman. Jahe mengandung senyawa antioksidan yaitu metil ester, 9oktadekonik dan nortraselogenin. Penelitian ekstrak bubuk kunyit dan asam tersebut memiliki perbandingan ekstrak kunyit 55\% dan ekstrak daun asam 45\% sehingga menghasilkan nilai $4,844 \%$. Kayu manis dapat menjadi sumber antioksidan karena mengandung banyak senyawa seperti eugenol, safrole, sinamaldehid, tannin, dan kalsium oksalat. Komponen aktif yang terkandung di dalam secang yaitu flavonoid. Buah andaliman memiliki potensi sebagai antioksidan dan inhibitor $\alpha$-glukosidase.
\end{abstract}

Kata Kunci : Antioksidan, radikal bebas, rempah, pangan fungsional

\begin{abstract}
Along with the development of an increasingly advanced era, people increasingly consume fast food or junk food. This is what causes the emergence of degenerative diseases based on lifestyle. So that comes the functional food concept. Functional food is food or drink that has physiological functions on the body. For example, consuming antioxidants to counteract free radicals that occur in the body. This source of natural antioxidants can come from various types of plants such as fruits, vegetables, spices, tea, or enzymes and proteins. As we have seen, Indonesia is a country rich in spices. This spice can be used as a source of natural antioxidants that have many benefits for the body. The types of spices in Indonesia are ginger, turmeric, cinnamon, secang, and andaliman. Ginger contains antioxidant compounds, namely methyl ester, 9-octadeconic and nortraselogenin. The study of turmeric and acid powder extracts had a comparison of 55\% turmeric extract and $45 \%$ acid leaf extract resulting in a value of $4.844 \%$. Cinnamon can be an antioxidant source because it contains many compounds such as eugenol, safrole, cinnamaldehyde, tannin, and calcium oxalate. The active components contained in the cage are flavonoids. Andaliman fruit has the potential as an antioxidant and $\square$-glucosidase inhibitor.
\end{abstract}

Keywords : Antioxidant, functional product, free radicals, spices. 


\section{PENDAHULUAN}

Seiring dengan perkembangan zaman yang semakin maju, masyarakat semakin sering mengkonsumsi makanan cepat saji atau junk food. Hal ini menyebabkan banyaknya penyakit degeneratif yang muncul di kalangan masyarakat sehingga telah mengubah pandangan bahwa makanan tidak hanya memiliki cita rasa yang enak, mengenyangkan, dan tampilan yang menyenangkan tetapi juga dapat bermanfaat bagi tubuh dalam segi kesehatan. Hal inilah yang memunculkan suatu konsep pangan fungsional (Winarti \& Nurdjannah, 2005).

Pangan fungsional merupakan suatu produk baik itu makanan atau minuman yang dapat memberikan keuntungan untuk dapat mempengaruhi fungsi fisiologis terhadap meningkatnya kesehatan tubuh sehingga dapat mencegah suatu penyakit (Marsono, 2008). Pangan fungsional tidak berupa suplemen, serbuk, ataupun kapsul melainkan berasal dari bahan yang terdapat secara alami sehingga dapat dikonsumsi sebagai makanan sehari-hari. Pangan fungsional memiliki karakteristik sensori dalam segi penampakan, warna, tekstur maupun citarasa yang dihadirkan, dan dapat diterima oleh masyarakat yang mengkonsumsinya, serta tidak memiliki efek samping yang berbahaya bagi tubuh (Winarti \& Nurdjannah, 2005). Pangan fungsional memiliki peran yang dapat memperkuat mekanisme tubuh, mencegah timbulnya penyakit degeneratif seperti hipertensi dan kanker, memperlambat proses penuaan, dan menjaga kondisi tubuh. manfaat-manfaat inilah yang membedakan pangan fungsional dengan yang lainnya (Marsono, 2008).

Salah satu jenis penyakit degeneratif yang saat ini banyak diderita yaitu penyakit kanker. Penyakit kanker terjadi karena adanya reaksi oksidasi yang berlebihan di dalam tubuh sehingga akan memunculkan radikal bebas yang dapat akan melakukan mutasi dan merusak struktur dan fungsi sel. Tingginya kadar radikal bebas di dalam tubuh terjadi karena rendahnya aktivitas antioksidan (A. N. Sari, 2016). Sumber antioksidan alami ini dapat berasal dari berbagai jenis tumbuhan seperti buahbuahan, sayur-sayuran, rempah-rempah, teh, ataupun enzim dan protein (Rahmi, 2017). Aktivitas antioksidan terdapat pada tanaman karena tanaman tersebut mengandung senyawa metabolit sekunder seperti flavonoid, fenolik, tannin, dan antosianin.

Seperti yang telah kita ketahui, Indonesia merupakan negara yang kaya akan rempah-rempah. Rempah-rempah ini dapat digunakan sebagai sumber antioksidan alami yang memiliki banyak manfaat bagi tubuh. Akan tetapi, tidak adanya publikasi yang meluas terhadap informasi tersebut sehingga hanya sebagian kecil saja yang mengetahui jenis-jenis rempah apa yang banyak mengandung antioksidan. Sehingga tulisan ini akan mengulas beberapa jenis rempah dalam segi khasiat atau manfaatnya terhadap fungsi fisiologis pada tubuh.

\section{PEMBAHASAN}

Antioksidan dapat ditemukan dari bahan golongan rempah-rempah yang umumnya telah dikenal di masyarakat.

\subsection{Jahe}

Jahe merupakan jenis rempah-rempah yang sering digunakan sebagai bahan tambahan dalam pembuatan kue, permen, sebagai bumbu masak, pembuatan obat herbal seperti jamu. Jahe memiliki aktivitas 
antioksidan karena mengandung senyawa fenol oleoresin seperti gingerol dan shogaol. Jahe memiliki zat utama gingerol yang dapat menurunkan kadar glukosa darah dan meningkatkan produksi dari hormon insulin. Jahe memiliki senyawa zingiberen dan zingiberol yang membuat jahe terasa pedas saat dikonsumsi. Menurut (Purnama, Jaya, \& Widjanarko, 2010), jahe mengandung senyawa antioksidan yaitu metil ester, 9oktadekonik dan nortraselogenin. Total senyawa dari zingerone yaitu dari 5,68\% menjadi 6,32\%. Rendemen jahe yang didapatkan dari penelitian (Saragih, Assa, \& Langi, 2014), menghasilkan sebesar $6,78 \%$.

\subsection{Kunyit}

Kunyit merupakan jenis rempahrempah yang memiliki aktivitas antioksidan yang paling tinggi. Kunyit memiliki senyawa yang paling penting yaitu komponen kurkuminoid seperti kurkumin, demetoksikurkumin, dan bisdemetoksikurkumin. Senyawa kurkuminoid ini memiliki potensi sebagai antioksdian alami yang telah diteliti sebagai anti inflamasi, antioksidan, antibakteri, dan kardiprotektif. Kunyit dalam penelitian (Riaminanti, Hartiati, \& Mulyani, 2016) telah terbukti memiliki aktivtas antioksidan yang apabila dicampurkan dengan asam maka akan menunjukkan adanya sinergisme antioksidan tertinggi. Penelitian ekstrak bubuk kunyit dan asam tersebut memiliki perbandingan ekstrak kunyit $55 \%$ dan ekstrak daun asam $45 \%$ sehingga menghasilkan nilai $4,844 \%$. Senyawa antioksidan dari kedua bahan tersebut sehingga menghasilkan antioksidan tertinggi. Senyawa-senyawa tersebut adalah fenolik dan vitamin C. Nilai sinergisme ini dipengaruhi oleh kemampuannya untuk menangkal radikal bebas dengan jumlah fenol yang lebih banyak. Sehingga komponen fenolik ini dapat menghambat pertumbuhan kanker dan memiliki aktivitas antimutagenik. Kunyit memiliki manfaat untuk menghilangkan kerutan, tanda penuaan, obat maag, dan diare.

Penelitian (Simangunsong, Mulyani, \& Hartiati, 2018), mendapatkan bahwa ektrak kunyit dapat dijadikan sebagai produk antiaging. Hal ini karena penuaan terjadi karena adanya kerusakan metabolik dan kematian seluler. Antioksidan dari kunyit inilah yang digunakan untuk dapat mencegah paparan radikal bebas sehingga akan melindungi kulit dari penuaan dini. Sehingga didapatkan dari formulasi pertama dengan karakteristik $\mathrm{IC}_{50}$ sebesar $48,39 \mu \mathrm{g} / \mathrm{mL}$.

\subsection{Kayu manis}

Kayu manis merupakan jenis rempahrempah yang sering diekspor dengan aroma khas berbentuk elips. Kayu manis banyak dimanfaatkan dalam meningkatkan cita rasa dan aroma. Kayu manis bersifat multi fungsi karena hampir semua bagian dapat dimanfaatkan mulai dari kulit, cabang, dan dahan. Selain sebagai rempah-rempah, kayu manis juga dapat digunakan untuk membuat produk minyak atsiri atau oleoresin. Kayu manis dapat menjadi sumber antioksidan karena mengandung banyak senyawa seperti eugenol, safrole, sinamaldehid, tannin, dan kalsium oksalat. Menurut (Ekaprasada, Nurdin, Ibrahim, \& Dachriyanus, 2009), ekstrak dari kulit kayu manis dapat menghasilkan senyawa simeladehid sebesar $68,65 \%$ sebagai sumber antioksidan untuk menangkal radikal bebas. Senyawa sinemaldehid termasuk dalam golongan fenilpropanoid atau senyawa turunan fenol yang berperan penting dalam aktivtias antioksidan. 
Pada penelitian (Yuliarto, Khasanah, \& Anandito, 2012), produk minyak atsiri kulit kayu manis (Cinnamomum burmannii) dengan menggunakan metode destilasi uapair mendapatkan senyawa sinemaldehid (37,12\%), p-Cineole $(17,37 \%)$, Linalool $(8,57 \%)$, dan Benzyl benzoate $(11,65 \%)$. Metode dengan destilasi uap-air ini memberikan nilai yang lebih besar dibandingkan dengan metode destilasi air. Hal ini karena terjadinya proses dekomposisi minyak yang lebih kecil. Sedangkan pada penelitian (Adi, Khasanah, \& Anandito, 2014), produk oleoresin kulit kayu manis dengan metode ekstraksi mendapatkan senyawa sinemaldehid sebesar $12,22 \%$. Perbedaan senyawa sinemaldehid yang didapatkan bergantung dengan metode apa yang digunakan dan mutu dari kulit kayu manis tersebut. Sinemaldehid dan Linalool telah dilaporkan sebagai senyawa antioksidan (Saleh, Clark, Woodard, \& Deolu-sobogun, 2010)

\subsection{Secang}

Secang merupakan jenis rempahrempah yang banyak dikonsumsi sebagai minuman kesehatan. Secara umum, komponen aktif yang terkandung di dalam secang yaitu flavonoid. Saponin, polifenol, dan tannin sehingga secang ini berpotensi sebagai antioksidan alami penangkal radikal bebas dengan indeks antioksidatif yang lebih tinggi dibandingkan antioksidan sintetis. Selain itu, antioksidan alami dapat menghasilkan residu yang lebih mudah terdegradasi secara alami daripada antioksidan sintetik. Kayu secang dapat digunakan dalam bidang farmasi sebagai obat luka, batuk berdarah, penawar racun, desinfektan dan sebagai anti bakteri, anti inflamasi, anti tumor, dan anti kanker (R. Sari \& Suhartati, 2016)
Secang sebagai antikanker atau sitotoksik dapat digunakan sebagai agen kemoterapi untuk menghambat metabolisme kanker pada tubuh. Berdasarkan hasil penelitian (Hanif, Dina, Esti, Taufik, \& Susidarti, 2017), yang mendapatkan bahwa ektrak etanolik kayu secang atau EEKS dapat berpotensi menjadi agen kemopreventif pada hasil uji sitotoksik terhadap sel kanker payudara 4T1. Akan tetapi, efek sitotoksik ini tidak ditimbulkan dari jalur ROS atau Reactive Oxygen Species. Kandungan brazilein dari secang memiliki aktivitas antikanker dengan menghambat protein dari inhibitor apoptosis survivin dan kandungan brazilim dapat melindungi dari keracunan radikal kimia.

\subsection{Andaliman}

Andaliman merupakan jenis-jenis rempah yang banyak digunakan oleh masyarakat batak sebagai bumbu masakan. Buah andaliman memiliki potensi sebagai antioksidan dan inhibitor $\alpha$-glukosidase. Ektrak dari buah andaliman memiliki aktivitas antioksdian yang paling baik dengan $\mathrm{IC}_{50}$ mencapai 30,04 ppm. Fraksi C ( $\left.\mathrm{IC}_{50} 16 \mathrm{ppm}\right)$ memiliki aktivitas sebagai inhibitor $\alpha$-glukosidase yang paling aktif dan juga mengandung senyawa flavonoid golongan aurond an flavanon yang bersifat sebagai senyawa yang paling aktif sebagai inhibitor $\alpha$-glukosidase (Gultom, 2011).

Andaliman bermanfaat dalam bidang farmasi menjadi senyawa aromatik dan minyak esensial. Andaliman dapat digunakan sebagai perangsang nafsu makan karena memiliki aroma yang khas dan rasa pedas, sebagai tonik, dan bersifat antibakteri (Asbur \& Khairunnisyah, 2018). Andaliman juga dapat berfungsi sebagai bahan pengawet alami terkait dengan antioksidan dan antibakterinya. Andaliman 
mengandung senyawa kuinon, polifenolat, flavonoid, alkaloid, dan terpenoid.

\section{KESIMPULAN}

Jenis rempah-rempah yang telah diulas tersebut dapat dijadikan sebagai bahan baku dengan konsep pangan fungsional. Pangan fungsional yaitu makanan atau minuman yang dapat memberikan fungsi fisiologis pada tubuh misalnya dengan antioksidan. Sehingga produk-produk ini akan mengandung sumber antioksidan yang tinggi dengan bahan baku yang terjangkau dan bersifat alami dan tidak beracun saat dikonsumsi.

\section{DAFTAR PUSTAKA}

Adi, D. N., Khasanah, L. U., \& Anandito, B. K. (2014). Produksi Oleoresin Berbahan Baku Limbah Destilasi Kayu Manis (Cinnamomum burmanii). Jurnal Teknologi Hasil Pertanian, 7(1), $1-11$.

Asbur, Y., \& Khairunnisyah. (2018). Pemanfatan Andaliman (Zanthoxylum acanthopodium DC ) sebagai Tanaman Penghasil Minyak Atsiri. Jurnal Kultivasi, 17(1), 537-543.

Ekaprasada, M. T., Nurdin, H., Ibrahim, S., \& Dachriyanus. (2009). CHEMICAL COMPOSITION AND

ANTIBACTERIAL ACTIVITY OF THE ESSENTIAL OIL OF THE Toona sureni (Blume) Merr. Jurnal Ris. Kim, 3(1), 90-95.

Gultom, S. (2011). Flavonoid Buah Andaliman (Zanthoxylum acanthopodium DC) sebagai Antioksidan dan Inhibitor aGlukosidase. Skripsi. Institut Pertanian Bogor.

Hanif, N., Dina, A., Esti, Y. F., Taufik, M. A., \& Susidarti, R. A. (2017). Ekstrak Etanolik Kayu Secang (Caesalpinia Sappan L.) Menunjukkan Efek Sitotoksik pada Sel Kanker Payudara 4t1 Tetapi Tidak Melalui Jalur
Reactive Oxygen Species (Ros). Jurnal Kimia Farmasi UGM, 10(2), 55-62. https://doi.org/10.22435/toi.v10i2.719 5.55-62

Marsono, Y. (2008). Prospek Pengembangan Makanan Fungsional. Jurnal Teknologi Pangan Dan Gizi, 7(1), 19-27.

Purnama, H., Jaya, F., \& Widjanarko, S. . (2010). The Effects of Type and Time of Thermal Processing on Ginger (Zingiber officinale Roscoe) Rhizome Antioxidant Compounds and its Quality. International Food Research Journal, 17, 335-347.

Rahmi, H. (2017). Aktivitas Antioksidan dari Berbagai Sumber Buah-buahan di Indonesia. Jurnal Agrotek Indonesia, 2(1), 34-38.

Riaminanti, N. K., Hartiati, A., \& Mulyani, S. (2016). Studi Kapasitas dan Sinergisme Antioksidan pada Ekstrak Kunyit (Curcuma Domestica Val.) dan Daun Asam (Tamarindus Indica L.). Jurnal Rekayasa Dan Manajemen Agroindustri, 4(3), 93-104.

Saleh, M. A., Clark, S., Woodard, B., \& Deolu-sobogun, S. A. (2010). Antioxidant and Free Radical Scavenging Activities of Essential Oils. Ethnicity and Disease, 20, 78-82.

Saragih, J., Assa, J., \& Langi, T. (2014). Aktivitas Antioksidan Ekstrak Jahe (Zingiber officinale var. rubrum) Menghambat Oksidasi Minyak Kacang Tanah (Arachis hypogaea L.). Jurnal Fakultas Pertanian UNSRAT, 1(1), 16.

Sari, A. N. (2016). Berbagai Tanaman Rempah sebagai Sumber Antioksidan Alami. Journal of Islamic Science and Technology, 2(2), 203-212.

Sari, R., \& Suhartati. (2016). Secang (Caesalpinia sappan L.): Tumbuhan Herbal Kaya Antioksidan. Info Teknis Eboni, 13(1), 57-67.

Simangunsong, F. M. P., Mulyani, S., \& Hartiati, A. (2018). Evaluasi Karakteristik Krim Ekstrak Kunyit (Curcuma domestica Val.) pada 
Berbagai Formulasi. Jurnal Rekayasa Dan Manajemen Agroindustri, 6(1), $11-21$.

Winarti, C., \& Nurdjannah, N. (2005). Peluang Tanaman Rempah dan Obat sebagai Sumber Pangan Fungsional. Jurnal Litbang Pertanian, 24(2), 4755.

Yuliarto, F. T., Khasanah, L. U., \& Anandito, R. B. K. (2012). Pengaruh Ukuran Bahan dan Metode Destilasi (Destilasi Air dan Destilasi Uap-Air) terhadap Kualitas Minyak Atsiri Kulit Kayu Manis (Cinnamomum burmanii). Jurnal Teknosains Pangan, 1(1), 1223. 